\title{
Uso de drogas: a alter-ação como evento ${ }^{1}$
}

\author{
Eduardo Viana Vargas ${ }^{2}$ \\ Professor adjunto de Antropologia - UFMG
}

RESUMO: Este artigo problematiza o elenco de questōes e de respostas que costumamos formular a respeito dos usos de drogas e propõe outro modo de pensar essas práticas. Sugere-se que já não é mais suficiente indagar "por que as pessoas usam drogas?" e "qual o significado do uso de drogas?", nem se contentar com as respostas que são apresentadas quando essas questôes são colocadas, pois elas costumam concluir pelo "erro", pela "falta" ou pela "fraqueza”. Propõem-se, então, outras questōes: "o que ocorre em práticas como essas?", "que experiência usuários e substâncias realizam?”. Conseqüentemente, propõem-se também outras respostas. Estas novas respostas apontam para a existência de eventos - as 'ondas' das drogas - que envolvem agenciamentos paradoxais de auto-abandono. Propõe-se que o evento 'onda' não resulta de fantasias subjetivas dos usuários, nem de determinações objetivas da substância, mas exige modalidades de (in)ação como aquelas presentes no paradoxo da paixão e nos jogos profundos. Sustenta-se que o evento 'onda' envolve modos singulares de engajamento no mundo, nos quais as substâncias são mediadores indispensáveis. Por fim, sugere-se que, em vez de se indagar quem controla a 'onda', cabe perguntar se ela ocorre ou não, ou, baseado em Gabriel Tarde, se há ou não alter-ação.

PALAVRAS-CHAVE: drogas, medicamentos, evento, ação, Gabriel Tarde. 


\section{Consenso moral e práticas recalcitrantes}

Uma impressionante uniformidade marca as políticas oficiais sobre drogas que vigoram contemporaneamente em quase todos os países do mundo. Essas políticas são uniformes ao menos nos seguintes aspectos: elas estabelecem uma distinção entre "drogas" e "fármacos", valendo-se, para tanto, de critérios biomédicos; elas apresentam uma tendência à crescente ampliação da lista de substâncias consideradas de uso ilícito; e elas são políticas "antidrogas" que, enquanto tais, implicam a criminalização da produção, da distribuição e do consumo de drogas com propósitos não terapêuticos, salvo notórias e notáveis exceções como as do álcool, do tabaco e dos produtos que Sidney Mintz (1985, pp. 180 e 186) apropriadamente chamou de "alimentos-droga", como o chá, o café e o chocolate. Embora seja possível encontrar exceções a essa regra, ${ }^{3}$ as políticas antidrogas emprestaram força de lei a um consenso moral que se tornou amplamente difundido e que, sinteticamente, se expressa nos seguintes termos: drogas causam dependência, fazem mal, quando não matam pura e simplesmente; usá-las, portanto, é um absurdo; logo, "diga não às drogas".

Não obstante sua força atual, e embora retire boa parte de sua energia precisamente do expediente que o faz passar por um dado estabelecido, esse consenso moral não é, entretanto, auto-evidente. Prova disso é que a ênfase repressiva das políticas antidrogas atualmente em vigor contrasta nitidamente com a leniência das que vigoravam há pouco mais de um século, quando praticamente nenhuma droga, de uso medicamentoso ou não, estava sujeita à criminalização. ${ }^{4}$

Não é o caso aqui de narrar como essa situação mudou tão drasticamente e como foi possível alcançar uma uniformidade tão notável nas políticas oficiais a respeito de um tema tão controverso; também não é o caso de listar as razões pelas quais nem o contingente de usuários nem 
o montante de drogas consumidas parecem ter diminuído significativamente no último século, tudo levando a crer que o que se deu foi o contrário, com as práticas contemporâneas de consumo de drogas apresentando uma obstinação, como se diz, alarmante. ${ }^{5}$

Meu propósito aqui é outro: tomando como ponto de partida a recalcitrância das práticas, procuro mostrar que o consenso moral não é o único que se apresenta quando o assunto é o consumo de drogas; ao contrário, ele é inseparável de ao menos outros dois, um concernente às questóes que os especialistas no assunto costumam colocar, outro ao gênero de respostas que convencionalmente são dadas a elas. Neste trabalho sugiro que as questões que nos habituamos a colocar não são as únicas possíveis, nem as mais importantes, e que as respostas apresentadas se equivocam ao fundamentar as práticas no erro ou em algum de seus vizinhos semânticos. Proponho que, em vez de indagar o porquê ou qual o significado do uso de drogas, cabe perguntar o que ocorre ou que experiência os usuários atualizam mediante o consumo, questóes que exigem outro modo de problematização do uso de drogas. Minha hipótese de trabalho é que o que ocorre são eventos (refiro-me àquilo que os usuários costumam chamar de 'barato', 'viagem' ou 'onda' das drogas) e que esses eventos implicam experimentaçóes intensivas e autoabandono, ou o paradoxo de açóes que deliberadamente visam 'sair de si'. Assinalo, em apoio a essa hipótese, que os usos medicamentosos e não medicamentosos de drogas requerem meticulosa preparação e que não é possível distingui-los de modo absoluto, mas somente com base nos agenciamentos que os mobilizam enquanto tais. Procuro mostrar que, se a 'onda' é um evento, é porque ela não resulta nem de fantasias subjetivas dos usuários, nem de determinações objetivas da substância, mas desenvolve modalidades de (in)ação como aquelas presentes no paradoxo da paixão. Proponho que os consumos não medicamentosos de drogas são como "jogos profundos”, isto é, práticas que envolvem 
modos singulares de engajamento no mundo, nos quais as substâncias são mediadoras indispensáveis para a produção de alter-açôes. Sugiro, então, que a questão decisiva não é indagar quem controla a 'onda', posto que esta, enquanto alter-ação, é sempre uma ação de outrem, mas perguntar se há ou não há 'onda', ou seja, se ela ocorre ou não. Retorno, por fim, ao ponto de partida para insistir que recusar o consenso moral não significa fazer apologia às drogas, mas alimentar a controvérsia em busca de alternativas conseqüentes que levem em conta a afirmação eticamente sustentada da pluralidade imanente dos modos de existência.

\section{Para perguntas equívocas, só o erro é resposta}

O consenso moral não é o único agenciado em torno das drogas, sendo possível notar a existência de outros consensos, desta vez analíticos, posto que associados quer às questôes que costumamos endereçar ao uso de drogas, quer ao gênero de respostas que, especialistas no assunto, nos acostumamos a dar a essas questóes.

Intrigados com o descompasso abissal entre a avaliação de que o consumo não medicamentoso de drogas é prejudicial, quando não letal, e a tenacidade das práticas de uso não medicamentoso de drogas, que resistem apesar do vigor dos expedientes repressivos que procuram contêlas, habituamo-nos a levantar as seguintes questôes: "por que as pessoas usam drogas?" ou, então, "o que significa usar drogas?".

Por sua vez, as respostas que os especialistas costumam dar a essas questôes apresentam, bem aquém das diferenças disciplinares que elas expressam, uma regularidade não menos impressionante: o porquê ou o significado do uso de drogas são regularmente imputados a uma falta ou fraqueza, física e/ou moral, psíquica e/ou cultural, política e/ou social. Dito de um modo mais prosaico, habituamo-nos a pensar que o consu- 
Revista de Antropologia, São Paulo, USP, 2006, v. 49 no 2.

mo de drogas seria uma resposta a uma crise ou a uma carência qualquer: consomem-se drogas porque faltam saúde, afeto, cultura, religião, escola, informação, dinheiro, família, trabalho, razão, consciência, liberdade etc., como é possível depreender do capítulo "Theories and Interpretations of Illicite Drug Use", do World Drug Report, produzido há uma década pelo órgão da ONU dedicado às drogas ilícitas (UNODC, 1997, pp. 44-64), que sintetizo e comento a seguir.

Estudos no campo da neurobiologia, apoiados na constatação de que o corpo humano não só possui receptores orgânicos capazes de interagir quimicamente com opiáceos, estimulantes, alucinógenos e canabinóides, como também com secretas substâncias similares a essas drogas psicotrópicas, ${ }^{6}$ especulam sobre a existência de predisposições genéticas para o uso de drogas. ${ }^{7}$ Já psiquiatras e psicólogos em geral e psicanalistas em particular postulam que o uso de drogas é uma atitude regressiva de uma personalidade mal constituída, mal amadurecida, fixada numa busca narcisista do prazer, uma atitude escapista e infantilizante por meio da qual se foge das responsabilidades e da realidade do mundo adulto em favor de uma busca obsessiva e ingênua por "orgasmos farmacológicos" (Olievenstein, 1970, p. 68). ${ }^{8}$ Os cientistas sociais, por sua vez, tendem a rejeitar a idéia de predisposições psicofisiológicas para o uso de drogas e a enfatizar, ao menos por obrigação de ofício, os aspectos socioculturais. Ainda assim prevalece, mesmo aqui, a noção de que o uso de drogas é devido a alguma espécie de falta ou fraqueza. Assim, certos antropólogos consideram que os usos de drogas, ao menos os ocidentais contemporâneos, bem como outras práticas que envolvem uma "atração irracional para as figuras inumeráveis do risco" (Le Breton, 1991, p. 10), são todos tributários de uma "crise de sentido" provocada pelo avanço acelerado dos processos técnicos e sociais da modernidade e caracterizada pela perda dos referenciais simbólicos que permitiriam aos atores orientarem-se de modo seguro no mundo. ${ }^{9}$ Já os sociólogos que produziram 
os estudos hoje reputados clássicos sobre o assunto tendem a considerar os usos de drogas ilícitas como práticas "desviantes" de normas morais socialmente instituídas; nesse compasso, reconhecem o caráter provisório das normas tão prontamente quanto edificam as normas como parâmetro definitivo, já que é sempre em relação a alguma delas que o desvio se apresenta enquanto tal. ${ }^{10}$ As noçôes de falta, falha ou fraqueza também são recorrentes nas abordagens baseadas na teoria da escolha racional, que postulam que os indivíduos agem calculando meios para maximizar benefícios e minimizar custos, e consideram que a aparente irracionalidade dos usos não medicamentosos de drogas é tributária de uma avaliação enviesada, marcada pela desinformação ou pelo auto-engano dos usuários; nas abordagens de inspiração marxista ou existencialista, considera-se o uso não medicamentoso de drogas como "alienação" ou alheamento das reais condições de existência, logo, como práticas caracterizadas pelo fracasso ou pelo equívoco (ou, numa palavra, pela "ideologia") na apreensão das condições reais de existência; e, nas abordagens de inspiração mertoniana, considera-se o uso não medicamentoso de drogas como resultante de processos "anômicos", vale dizer, de processos pautados pelo fracasso na imposição de regras capazes de estabelecerem solidariedade social e pela ruína dos meios socialmente prescritos para se alcançar objetivos culturalmente definidos. ${ }^{11}$

Obviamente, o recenseamento que acabo de fazer é sumário, para dizer o mínimo. Não obstante, ele permite perceber que é sob os modos do defeito físico ou da falha psicológica, da perda dos referenciais simbólicos ou do desvio moral, dos erros de informação, da alienação ou do fracasso das regras sociais que o problema do uso ilícito de drogas vem sendo majoritariamente considerado entre nós. Essas noções de falta, falha, erro, crise ou perda são tão incisivas e recorrentes que podemos encontrar no World Drug Report a seguinte pérola: 
Revista de Antropologia, São Paulo, USP, 2006, v. 49 no 2.

[...] uma justificativa mais ampla [para o uso ilícito de drogas] pode ser encontrada no postulado segundo o qual as propriedades aditivas das drogas psicoativas são tais que os indivíduos que as consomem perdem o status de seres governados pela razão - se eles não são mais "os melhores zeladores de seu próprio bem-estar", seu comportamento desafia a autonomia pessoal em que o modelo do ator racional se baseia. Para parafrasear isso em termos kantianos, o consumidor de drogas ilícitas não é um agente racional. Pode-se assim argumentar que a proibição é do interesse do bem comum porque o comportamento que mina a auto-regulação e o autocontrole é potencialmente uma ameaça à sociedade liberal. (UNODC, 1997, p. 156)

Se o tempo dos paraísos artificiais já não é mais o nosso, se hoje as drogas são o inferno, como disse Francis Caballero (1992, p. 13), ou o "reencantamento do mal", como apontou Alba Zaluar (1993), é porque prevalece entre nós a percepção segundo a qual o consumo continuado e não medicamentoso de drogas traria efeitos deletérios ao desenvolvimento das sociedades e, com elas, da própria humanidade, pois produziria sujeitos que, ao perderem a vontade própria, perderiam também a própria condição de sujeito, ou seja, tornar-se-iam "alienados", "autômatos", "zumbis". ${ }^{12}$

Pelo momento, o ponto que gostaria de destacar é o seguinte: as questôes do "por que" ou do "significado" dos usos não medicamentosos de drogas não são as únicas que podem ser postas, nem, creio, as mais relevantes, como procurarei mostrar mais adiante. Antecipo apenas que elas não são as mesmas colocadas pelos próprios usuários que, habitualmente, se mostram pouco interessados em saber por que usam drogas ou qual o significado dessas práticas, salvo quando os analistas ou outras autoridades os indagam. Antecipo ainda que elas condicionam de antemão o gênero de respostas que nos habituamos a considerar, já que, 
como acabamos de observar, às perguntas suscitadas pela consideração das práticas de uso de drogas como disparatadas, as respostas aventadas (que procedem, via de regra, por redução de absurdo) só são capazes de apresentar soluçóes se concluem pelo erro, pela falta, pela fraqueza ou por algum outro de seus vizinhos semânticos.

\section{Outras questóes, outro modo de problematização}

Esse gênero de respostas sempre me pareceu insatisfatório: ele é epistemologicamente negativo e faz do consumo de drogas "mero produto de uma precariedade criada por outros", como escrevera Janice Caiafa (1985, pp. 17-18); ${ }^{13}$ ele é assimétrico e não apenas supõe como dada a partilha moral entre drogas lícitas e ilícitas, como também explica o uso das primeiras pelo acerto e o das segundas pelo erro $;^{14}$ ele desconsidera o que tenho chamado de dispositivo das drogas, dispositivo caracteristicamente ambivalente implicado na produção simultânea dos medicamentos e das drogas de uso ilícito; ${ }^{15}$ e, enfim, ele perde de vista o gênero de questóes que os próprios usuários costumam se colocar.

A respeito deste último ponto, Emilie Gomart e Antoine Hennion (1999, p. 242), assim como François Dagognet e Philippe Pignarre (2005, p. 342), já assinalaram que indagar por que as pessoas usam drogas ou o que significa usar drogas não é colocar as boas questôes. Em vez dessas, talvez seja mais adequado colocar questôes mais pragmáticas, mais próximas dos modos peculiares de funcionamento dessas experiências. Assim, sugerem Gomart e Hennion (1999, p. 242), cabe indagar: "o que ocorre", "o que acontece" nesse tipo de experiências? Ou, como o fazem Dagognet e Pignarre (2005, p. 342), "que experiência, aqueles que as consomem, fazem com as substâncias?”. Esse gênero de questóes tem, no mínimo, a vantagem de estar bem mais próximo 
daquelas que os próprios usuários se colocam, os quais volta e meia se perguntam em seus termos característicos: 'e aí, fez?', 'bateu?', 'o que está rolando?', 'qual é o barato?', 'qual é a onda?.

Certamente não se trata, com esse novo gênero de questões, de inverter o tipo de respostas dado ao primeiro gênero e dizer que o consumo de drogas não é baseado no erro, mas no acerto. Se fosse para proceder desse modo, não só poríamos a perder toda a crítica que cabe endereçar ao primeiro gênero de respostas, já que as novas respostas só seriam novas por efeito de inversão, como também teríamos mantido, ainda que sub-repticiamente, o mesmo conjunto anterior de questões. Nada mais equívoco, neste caso, do que simplesmente inverter as cartas do jogo, enquanto se continua a jogar com o mesmo baralho...

Em vez disso, considero bem mais proveitoso tratar do assunto em termos de lógica social, desde que isso seja feito conforme a acepção emprestada a essa expressão por Gabriel Tarde, que a concebe como "a arte de mudar de pensamentos conservando sempre, sem aumento nem diminuição, a distância que nos separa do verdadeiro ou do falso" (Tarde, 1895 b, p. 119). Assim considerada, a lógica social não diz respeito à busca ou à revelação da verdade, mas à direção dos agenciamentos (ou das ondas de crenças e de desejos, dizia Tarde) que animam o campo social.

Tratando do assunto desse modo, não é apenas o tipo de respostas que se altera, sem que essa alteração se resuma a uma mera inversão, mas é o próprio pensamento que muda, como se transforma o modo mesmo de problematização do tema em questão. E ele muda à medida que nos tornamos capazes de resistir à tentação de substituir as surpreendentes expressões dos atores por conhecidos repertórios de explicação (os quais os atores ignorariam por esses repertórios supostamente se esconderem em dimensões ou em substratos que, entorpecidos pela própria efetuação das ações, os atores seriam incapazes de alcançar), ou, o que vem a dar no mesmo, à medida que somos capazes de seguir de 
perto os passos dos próprios atores, como notou Bruno Latour (2005, p. 49), d'après Garfinkel, of course.

\section{O evento 'onda' e a fórmula do êxtase}

Ismael*: As pessoas [que usam drogas] falam: 'bateu?', 'bateu!'. Falam também: 'onda', 'não deu onda', 'ligou'. [...]

Quando você consegue ver exatamente o limiar entre um estado de consciência e outro estado de consciência, você chama essa passagem de 'bateu', ou 'ligou'.

Mickey*: Dá aquele estalo.

Sol*: Pois é, cê fica viajando. Ádma*: [...] é um canal que você vira, [...] você fuma e troca o canal.

Cibele*: Barato é o que te tira do centro. Igor*: Ah, o barato é cê [...] ficar na onda. Esse é que é o barato, entendeu?

Curtir a onda, curtir umas loucuras diferentes mesmo. Juliana*: É uma alteração [...], você altera os sentidos mesmo, assim, [...], a forma de perceber...

Um dos pontos mais intrincados revelados pelo consumo não medicamentoso de drogas diz respeito àquilo que o antigo gênero de questôes considerava como um absurdo, ${ }^{16}$ ou seja, com o descompasso entre o conhecimento autorizado adquirido - segundo o qual as drogas fazem mal, produzem dependência, sofrimento e morte - e a persistência dos usuários na prática dessas atividades. Viu-se, no entanto, que esse descompasso havia levado os especialistas a desconsiderarem o que dizem ou fazem os usuários em prol de teorias que explicam suas açôes 
pelo erro e por seus vizinhos semânticos. Os usuários, no entanto, não parecem desconhecer os riscos envolvidos em suas práticas. ${ }^{17}$ Além, apesar, ou por conta exatamente disso, eles insistem sobre a ocorrência de eventos, ou sobre o que (se) passa, quando o consumo é efetuado.

'Bateu?', 'rolou?', 'fez?' são questões que os usuários se colocam e que visam à ocorrência de acontecimentos singulares: o 'barato', a 'viagem', a 'onda' da droga. Mas o que é o 'barato', a 'onda', a 'viagem'? É difícil dizer, é difícil expressar, é difícil representar, pois são eventos que 'rolam', que se desenrolam com a experiência, que acontecem mediante experimentação. Assim, quando solicitados a falar a respeito, os usuários costumam narrar experiências vividas em que 'rolou' o 'barato', a 'viagem', a 'onda': foi em tal lugar, em tal período do dia, estava com tais 'chegados', aí 'pintou' uma 'presença' e a droga foi consumida, aí eu fiquei (ou tudo ficou) 'alterado'. É difícil extrair mais do que isso, pois não há mais o que dizer além do que passa, do que se passa.

Mas o que é um evento? Acompanho aqui Latour (1999, pp. 320-4), que toma emprestado de Alfred North Whitehead (1920, p. 52; 1927, p. 73) a noção de evento para evitar os embaraços das teorias correntes da ação, em resumo, para evitar a redução da ação ao idioma da dominação, as infindáveis querelas entre indivíduo e sociedade, ou entre sujeito e estrutura como senhores da ação, bem como o gesto iconoclasta que parte o mundo em fatos e fetiches e não oferece alternativa além das posições opostas e complementares do realismo e do construtivismo, ou da dialética que pretende conciliar as duas posiçôes ao preço de escavar ainda mais fundo o fosso que as separa. Latour sugere que, no lugar da escolha cominatória entre um sujeito que fabrica e fatos dados desde o início, ou dos torvelinhos dialéticos que pretendem superá-la, cabe se colocar aquém dessa fratura e seguir os movimentos que nos fazem fazer algo que nos surpreende, já que "sempre que fazemos alguma coisa nós não estamos no comando, somos ligeiramente surpreendidos pela ação" 
(Latour, 1999, p. 321, grifos do autor). Como também notaram Gomart e Hennion (1999, p. 225), é porque um evento prolonga ações iniciadas em outros lugares, ao mesmo tempo em que as transforma de modo surpreendente, que se pode dizer que ele ocorre, emerge ou é da ordem dos acontecimentos.

E em que medida é possível e adequado considerar a 'onda' como um evento? É que, como todo evento, esse também tem de ser feito, vale dizer, minuciosamente fabricado e realizado; ainda como todo evento, seus resultados são imprevistos e, de um modo ou de outro, escapam àquilo que os condicionam e introduzem alguma surpresa, diferença ou alteração. Ainda como todo evento, a 'onda' é algo que passa, que se passa. E o que (se) passa com a 'onda' é um 'estalo', uma 'alteração' da percepção, uma 'fruição por outros estados de percepção', uma 'percepção intensa', uma 'intensificação da percepção', 'uma maior intensidade de percepção da vida', uma alteração que faz que os momentos sejam vividos 'intensamente', já que 'a vida só vale a pena se for vivida intensamente', como se ouve entre usuários.

Daí que, quando Losferatus* afirma que 'não fico me drogando, não; eu uso... saca?', não se trata, parece-me, de auto-engano ou de um mero eufemismo acionado como subterfúgio para dissimular uma prática moralmente condenada, mas da afirmação de experimentações em que o que está em jogo é da ordem do intensivo, ou de intensidades que são inseparáveis dos modos experimentais de sua efetuação: 'eu vivo agora intensamente, sacou? Não sei que hora qu' eu vou morrer, não vou ficar arrependido... Prefiro [me] arrepender das coisas que eu fiz do que das que eu não fiz, sacou?', assim falou Losferatus*.

O ponto a ser destacado é que esses modos experimentais abarcam a produção deliberada de alterações intensivas que 'trocam o canal' e 'te tiram do centro' e, dessa maneira, fazem emergir movimentos de transformação ou de deslocamento, os quais envolvem entrega ou renúncia, 
ou, para falar como Foucault (1967), a "dissolução do eu", ${ }^{18}$ vale dizer, a ocorrência de eventos sobre os quais nem os usuários, nem as drogas, detêm o controle, de eventos que escapam a uns e a outros, de eventos que, conseqüentemente, implicam doses mais ou menos elevadas de abandono ao curso da experiência ou ao desenrolar dos acontecimentos. O que torna, portanto, paradoxais as práticas de consumo não medicamentoso de drogas é que essas alterações intensivas que implicam abandono ou dissolução do eu são auto-engendradas, são voluntariamente visadas, são minuciosamente preparadas. Este ponto é decisivo: deslocamento, movimento para fora, arrebatamento, transformação, sair de si, não é essa exatamente a "fórmula do êxtase"? (Perlongher, 1990, p. 77). Dessa perspectiva é possível sintetizar nos seguintes termos o paradoxo do êxtase ou do evento 'onda' das drogas, quando este chega a ser produzido enquanto tal: fazer de tudo (ou quase...) para que aconteça algo que nos escapa desde o início...

\section{Drogas e medicamentos}

Esses acontecimentos, o 'barato', a 'viagem', a 'onda', não vêm de graça. Eles precisam ser meticulosamente preparados, inclusive material e tecnicamente. Entre outras coisas, e do ponto de vista do usuário, é necessário 'descolar' a droga, ou seja, consegui-la, o que já supõe a existência de cadeias de produção e de redes de distribuição, bem como a relativa habilidade dos usuários em circular por elas, ao menos até certo(s) ponto(s). 'Descolada' a droga, é necessário arranjar a 'quebrada', vale dizer, o local e/ou a situação propícia ao consumo. ${ }^{19}$ É necessário ainda saber preparar e usar a droga, isto é, tornar a substância apta ao consumo: 'apertar o baseado', 'esticar a carreira e preparar o canudo', 'aprontar o chá', 'diluir e encher a seringa', em suma, fazer as separações ou as 
misturas indispensáveis e preparar os dispositivos materiais imprescindíveis à administração da substância em tela; assim como dispor dos conhecimentos e meios técnicos necessários ao uso, tais como saber de que modo administrar a droga - tragar sem tossir, inalar sem espirrar, ingerir sem vomitar ou acertar a veia na hora de injetar -, e quais são as doses necessárias, sem as quais não há 'onda', e suficientes, além das quais a 'onda' desanda, dependendo do caso na forma de overdose.

Num certo sentido, é como os medicamentos. Como mostrou Madeleine Akrich em sua pequena antropologia do medicamento, entre a introdução de uma nova molécula no mercado e sua ação bioquímica sobre o corpo do paciente, as etapas não são transparentes, sendo necessária toda uma gama de atividades sociotécnicas para que a molécula saída do laboratório produza efeitos sobre os corpos dos pacientes:

[...] para que nós possamos alcançar o que é considerado como a ação terapêutica do medicamento, a saber, certa reação bioquímica, é necessário passar por uma longa lista de etapas que se desenrolam em lugares diferentes, do laboratório ao consultório, à farmácia e ao domicílio, ou mesmo a outros lugares, e que engajam uma série de atores, seja diretamente presentes - médico, farmacêutico, paciente, comprador do medicamento -, seja representados pelos objetos manipulados, como os laboratórios farmacêuticos, a previdência social ou as autoridades sanitárias. Esses objetos também são numerosos e diversos: receitas, vinhetas, prontuários, embalagens externas, embalagens em contato com o medicamento, bulas, contagotas, colher, copo etc. (Akrich, 1995, p. 131)

Esses longos caminhos não podem ser abstraídos ou colocados entre parênteses, pois se eles são marcados por transformações e reformulações diversas que implicam tantos desvios, são neles também que se trançam "os destinos cruzados dos medicamentos e dos doentes" (ibid.). 
Revista de Antropologia, São Paulo, USP, 2006, v. 49 no 2.

Os caminhos não são menos longos no caso das drogas ilícitas. No entanto, como aqui se trata de caminhos tornados ilícitos, as atividades sociotécnicas que eles supõem não envolvem, geralmente, manuais de instrução ou outros expedientes do gênero capazes de estabilizar os modos de uso de uma maneira minimamente não controversa, mas esquemas de ação mais ou menos ritualizados, estabelecidos de maneira intersubjetiva - ou por imitação, esse modo característico de repetição diferenciada, diria Tarde (1890) -, o que lhes empresta latitudes de variação bem mais consideráveis do que aquelas que se costumam observar no uso de medicamentos.

Considere-se, por exemplo, os usos não medicamentosos e os usos terapêuticos de drogas. Os usos não medicamentosos de drogas geralmente começam por iniciação, sendo os neófitos introduzidos nas novas práticas pela mediação de outrem. Os usuários costumam dizer que foi com os 'amigos', com o pessoal da 'turma', com a 'galera' que as primeiras experiências de consumo aconteceram; e também as que se seguiram, sendo os usuários com quem se partilha o consumo de drogas de uso ilícito não exatamente todo tipo de pessoa, mas, mais precisamente, 'todos os meus amigos', as 'pessoas que estão próximas'. Essa preferência pelos amigos como companhia no uso de drogas de uso ilícito contrasta, por sua vez, com a situação das bebidas alcoólicas, sobretudo quando se consideram os primeiros usos. Esse contraste é muito relativo, pois o álcool etílico também é uma droga cujo consumo é feito entre amigos, como afirmaram praticamente todos os usuários. Apesar disso, ele existe, tendo sido relatado em muitas ocasiões que o álcool etílico foi usado, ao menos nas primeiras vezes, em um 'ambiente familiar'. Essa preponderância dos amigos sobre os familiares como companhia no uso de drogas de uso ilícito, bem como a presença proporcionalmente maior de familiares como companhia no uso de bebidas alcoólicas, contrasta, por sua vez e nitidamente, com as condições em que o uso de 
psicotrópicos de uso controlado costuma ser efetuado, situação em que prevalece a indicação médica como razão alegada para o primeiro uso e para os usos subseqüentes. ${ }^{20}$

Há, portanto, ainda essa outra diferença a ser considerada. Como nota Pignarre (1997, p. 104, grifos do autor), enquanto os usos médicos ou terapêuticos de drogas tendem a se difundir por meio de "um sistema filiativo, vertical e hierárquico (do terapeuta que não toma o medicamento ao paciente que o toma)", os usos não medicamentosos de drogas tendem a se propagar segundo um sistema ou dispositivo epidêmico. Esse dispositivo epidêmico, por sua vez, aufere um lugar de destaque ao emprego por iniciação - por repetição variada ou contágio imitativo, diríamos ao modo de Tarde (1890) - daquilo que fazem amigos ou 'chegados'. Embora esses dois dispositivos não sejam excludentes, eles não funcionam segundo os mesmos registros: num caso, o dispositivo opera, grosso modo, mediante prescrições efetuadas por autoridades competentes que, enquanto tais, se abstêm de segui-las, enquanto o outro só opera por mediação de iniciadores capazes de compartilharem experiências adquiridas; num caso, o imperativo da ordem é quase incontornável (usa-se uma droga por conta de uma receita prescrita ou de uma ordonnance, como dizem os franceses), enquanto no outro se experimenta a partir de exemplos emprestados a outros; num caso, o desvio com relação à ordem prescrita é percebido como falta de colaboração ou índice de desinformação ou resistência, enquanto no outro o improviso, as adaptações e as variaçôes na experimentação fazem parte do modo próprio de funcionamento; num caso, a droga, enquanto um "abstrato forçado" (Pignarre, 1997, p. 104), é prescrita para um caso em particular, constituído pelo paciente com sua doença, e visa alcançar certos efeitos anteriormente estabelecidos (nos testes de laboratórios), enquanto no outro a droga é usada enquanto substância compartilhada por um coletivo e os efeitos da experimentação carregam uma alta dose de surpresa. 
Decerto, esses dispositivos também não põem em jogo os mesmos agenciamentos. Tocamos aqui num ponto capital, pois sucede às drogas e aos medicamentos o mesmo que às armas e às ferramentas. Como notaram Gilles Deleuze e Félix Guattari,

[...] sempre se pode distinguir as armas e as ferramentas segundo seu uso (destruir os homens ou produzir bens). Mas se essa distinção extrínseca explica certas adaptações secundárias de um objeto técnico, ela não impede uma convertibilidade geral entre os dois grupos, a ponto de parecer muito difícil propor uma diferença intrínseca entre armas e ferramentas. (1980b, p. 72)

"Ferramentas de trabalho e armas de guerra trocam suas determinações", como drogas e medicamentos também o fazem. "Isso não impede que se possam reconhecer diferenças interiores, embora não intrínsecas (lógicas ou conceituais), ainda que por aproximação", entre todas essas coisas, mas o ponto a ser destacado é que, tal como não é a ferramenta que define o trabalho, mas sim o inverso, não é a droga que define o crime, nem é o remédio que define a medicina: a droga supóe o crime, como o remédio supõe a medicina, e a ferramenta supõe o trabalho. De um lado, isso significa que, como as armas e as ferramentas, as drogas e os medicamentos estão "submetidos às mesmas leis que definem precisamente a esfera comum"; de outro, isso significa também que qualquer objeto técnico (arma, ferramenta, droga, remédio ou alimento) "continua abstrato, inteiramente indeterminado, enquanto não for reportado a um agenciamento" que o constitua enquanto tal (ibid.). 


\section{A 'onda' das drogas e o paradoxo da paixão}

Para melhor entender os agenciamentos efetuados no consumo não medicamentoso de drogas, retomemos os 'baratos', as 'viagens', as 'ondas' das drogas considerados como eventos ou acontecimentos. Em primeiro lugar, cabe notar que eventos como esses não resultam, observam Gomart e Hennion (1999, p. 227), nem de uma determinação objetiva da substância, nem de uma fantasia subjetiva do usuário. Como afirmam os usuários, é possível sair de si, abandonar-se, ultrapassar-se ou deixar-se ultrapassar por outros meios (como o sexo, a ioga, os esportes radicais e a religião..., entre outros meios citados), mas com as drogas a 'onda' é outra..., pois as substâncias - ou, melhor, os agenciamentos que as mobilizam enquanto mediadores ${ }^{21}$ - fazem diferença.

Pode-se colocar em dúvida, e é freqüentemente isso que os analistas fazem, muito do conteúdo das 'viagens' dos usuários: tratar-se-iam de divagações, delírios ou alucinações, o que a alcunha (atribuída, cabe lembrar, por não usuários) de certas drogas como "alucinógenos" corroboraria. No entanto, mesmo que os conteúdos dessas 'viagens' sigam além da conta ou levem as possibilidades imaginativas aos seus limites, as alterações produzidas não são, nem por isso, menos reais. ${ }^{22}$ Não estamos diante, portanto, de fantasias subjetivas dos usuários. Mas nem por isso estamos mais próximos de determinações objetivas por parte das substâncias, pois se os usuários são tomados pela droga ao tomá-las, eles nem por isso entram num estado de puro abandono, sendo incontáveis os procedimentos adotados pelos usuários para regrar minimamente as modalidades ou os graus de abandono: controle das doses, evitação de certas misturas, ingestão de outras substâncias capazes de minimizar ou, mesmo, de 'cortar' o 'barato' etc.

A situação de consumo e, como ela, a do auto-abandono, tem de ser, assim, minuciosamente produzida: embora freqüentemente a droga 
'pinte' ou 'role', isto é, apareça como um acontecimento desde o início, não menos freqüentemente é preciso 'correr atrás', vale dizer, fazer acontecer o evento 'onda' - que seja, ao menos, freqüentar os ambientes onde as chances de 'rolar' são otimizadas, quando não se trata de sair deliberadamente atrás da droga e da situação propícia para consumi-la.

Mas isso que é minuciosamente produzido também ultrapassa todas as previsões e resulta em eventos surpreendentes, pois se trata, precisamente, de um agenciamento que implica um 'sair de si', um auto-abandono - ou, como dizem os usuários, trata-se de 'ficar doidão', de 'sair do normal' ou da 'realidade' cotidiana e de perceber as coisas e pessoas segundo outro registro de realidade, segundo um registro propriamente intensivo de realidade. O ponto é que, ao 'sair de si', em maior ou menor medida, a situação necessariamente foge ao controle, pois essa fuga é, ela mesma, o agenciamento visado. Trata-se de um agenciamento arriscado, portanto; suas conseqüências são, por vezes, imprevisíveis, e nem todas são apreciadas enquanto tais pelos próprios usuários. ${ }^{23}$

Enfim, como lembram Gomart e Hennion, todo condicionamento requer que as condições sejam meticulosamente estabelecidas, já que um "trabalho ativo deve ser feito para que seja movido" (Gomart \& Hennion, 1999, p. 227). Da mesma forma, o auto-abandono, na medida mesmo em que é visado pelo próprio usuário, "nega a possibilidade de um 'puro' abandono" (ibid.). Esses agenciamentos supõem, portanto, quer um conjunto ativo de açóes por parte dos atores, quer um entregar-se não menos ativo a açôes que provêm de outras fontes, de outros agentes: deixar-se levar pelos efeitos das drogas, deixar-se manipular por elas, requer, paradoxalmente, uma manipulação ativa por parte dos usuários, e vice-versa. A passividade daí decorrente não indica um "momento de inação" ou "uma falta de vontade do usuário que repentinamente falha em ser um sujeito completo", notam Gomart e Hennion (id., p. 243), mas "se acrescenta à ação, potencializa a ação". 
Estamos longe, aqui, do modelo clássico dos atores racionais que agem no intuito de se fazerem sujeitos plenos de suas açóes, mas nem por isso estamos mais perto dos modelos sociológicos clássicos que supõem que os agentes são assujeitados desde o início por adscrições sociais. Em vez disso, como lembram Gomart e Hennion (ibid.), agenciamentos como esses colocam em jogo o clássico paradoxo da paixão, habitualmente descrito em casos de amor: "como pode alguém agir tão intensamente para que aconteça alguma coisa contra a qual não se pode fazer nada?". Como sugeri anteriormente, esse também é bem o paradoxo do êxtase ou do evento 'onda' das drogas: fazer de tudo (ou quase...) para que aconteça algo que nos escapa desde o início... Definido seja lá como for, esse paradoxo, veremos a seguir, envolve os que nele se engajam em jogos profundos.

\section{Jogos profundos e mediadores da alter-ação}

Jeremy Bentham, o filósofo utilitarista inglês que na virada do século XVIII para o XIX se tornou um dos principais proponentes da teoria do cálculo hedonista, cunhou o conceito de "jogo profundo" (deep play) para designar, como notara Clifford Geertz (1973b, p. 432) em seu conhecido ensaio sobre a briga de galos entre os balineses, jogos nos quais "as apostas são tão altas que, da perspectiva utilitarista, é irracional que os homens se engajem nele[s]". Sendo, do ponto de vista utilitarista, irracional participar de jogos como esse, já que nesse tipo de jogo os riscos envolvidos são superiores aos benefícios esperados, Bentham conclui, segundo Geertz, que o "jogo profundo é imoral" e que, portanto, "deveria ser legalmente proscrito" (id., p. 433). Contudo, ao analisar a briga de galos balinesa, Geertz tocou num ponto particularmente crucial: segundo ele, 
Revista de Antropologia, São Paulo, USP, 2006, v. 49 no 2.

mais interessante que o problema ético [levantado por Bentham], pelo menos quanto ao que aqui nos interessa, é que, apesar da força lógica da análise de Bentham, os homens engajam-se num tal jogo, freqüentemente e apaixonadamente, e mesmo diante de uma puniçāo legal. Para Bentham e os que pensam como ele (hoje em dia sobretudo advogados, economistas e alguns psiquiatras), a explicação é que [...] tais homens são irracionais viciados, fetichistas, crianças, tolos, selvagens que precisam ser protegidos contra eles mesmos. (ibid., grifos meus)

A solução que Geertz vai dar a esse problema é explicitamente culturalista, pois ela estabelece que, se os jogos profundos não respeitam os cânones do cálculo utilitário, é porque não existem nem foram criados para isso, mas sim para "expressar simbolicamente" códigos sociais: a briga de galos é um texto cultural, e o que os balineses póem em jogo nesse texto é mais do que dinheiro, e galos..., é o status de cada um. ${ }^{24}$

Se retomo aqui a temática dos jogos profundos é porque, embora nem Geertz nem Bentham façam tal conexão, qualquer semelhança entre as modalidades não médicas de consumo de drogas e os jogos profundos não me parece ser mera coincidência. No entanto, se a explicação utilitarista não é satisfatória porque não dá conta, a não ser assimétrica e negativamente, do fato de que as pessoas "engajam-se num tal jogo, freqüentemente e apaixonadamente", a alternativa apresentada por Geertz tampouco me parece adequada, pois ela põe a perder o veículo mesmo utilizado para "expressar simbolicamente" os códigos sociais: no presente caso, o uso de drogas! ${ }^{25}$

O problema é que o recurso aos argumentos da (ir)racionalidade e da "expressão simbólica" interdita, de antemão, que se considere a eficácia própria ao consumo de drogas de uso ilícito. Dessa maneira acaba-se por perder de vista o que há de produtivo no consumo de drogas, ou o que o evento 'onda' faz passar, a saber, outros modos de engajamento no 
mundo, maneiras mais ou menos adequadas de "a gente", enquanto "agentes", engajar-se no mundo, ou ainda, outras maneiras de ser "(a)gente" ${ }^{26} \mathrm{E}$ ele produz modos de engajamento no mundo que não são agenciados às expensas dos objetos, e que também não os tomam apenas como intermediários de um jogo teatral cuja cena principal se descortina em outros palcos, mas que se articulam com eles, mediadores indispensáveis, no caso, para que as agências se efetuem de modo 'alterado' ou, melhor, sob o modo de uma alter-ação. ${ }^{27}$

\section{Há o que existe: alter-ação}

Quem é, então, o senhor da ação?

Serão os indivíduos, agentes racionais autônomos que calculam hedonisticamente? Mas eles não são capazes de fazer o que quer que seja sem a intervenção de outros agentes, pessoas ou coisas, além de viverem se entregando, apaixonadamente, a esses jogos profundos onde arriscam mais do que têm, onde perdem mais do que ganham...

Serão, então, os organismos e suas predisposições psicofísicas? Mas elas são tão vagas, tão imprecisas, fazem tanto tábula rasa das operações necessárias para a realização de qualquer ação, e tampouco esclarecem como uns são capazes de parar, outros de se satisfazerem com pouco, outros de irem tão longe, outros de irem além...

Serão, então, as coisas, as propriedades intrínsecas das drogas? Mas, se existem, sejam elas quais forem, elas não dispensam nenhum dos artefatos necessários para produzi-las, nenhum dos artifícios necessários para pô-las em ação, enfim, nenhuma das mediações necessárias para que tais "propriedades intrínsecas" produzam, afinal, qualquer coisa que seja... 
Será, então, a sociedade? Mas o que é a sociedade fora das associações que a produzem enquanto tal? ${ }^{28} \mathrm{Ou}$ sem a multidão de objetos que a suportam enquanto tal? O problema decisivo aqui é que nunca é possível decidir de antemão quem conta e quem não conta como (a)gente, já que açôes são alter-açôes. ${ }^{29}$

Será, então, uma relação dialética dessas entidades tomadas duas a duas? Razão e organismo? Indivíduo e sociedade? Coisas e pessoas? Ou então um pouco de cada uma, como se a receita da maestria fosse o resultado da mistura apurada das doses certas de cada uma dessas entidades? Tampouco me parece o caso, pois tais misturas ou relações, postas dessa maneira, deixam intactas as "entidades" cujo acantonamento pretendem "superar".

Além disso, e esse ponto me parece decisivo, esses argumentos perdem de vista precisamente o 'barato', a 'viagem', a 'onda' das drogas, essa composição arriscada e imprevista entre agentes os mais diversos que não existe $(\mathrm{m})$ antes nem para além da própria composição.

Mais uma vez é necessário reconhecer que, posta nesses termos, a questão está mal colocada, pois remete sempre à distinção equívoca entre fatos e feitos, verdade e falsidade, certo e errado, dado e construído, razão e crença, quando nos parece mais proveitoso seguir os passos de Tarde e tratar desse assunto em termos de lógica social, ou seja, mantendo-nos a igual distância do verdadeiro e do falso e considerando as associaçôes que constituem a sociedade, não como um domínio à parte, mas como a "possessão recíproca, sob formas extremamente variadas, de todos por cada um" (Tarde, 1895a, p. 112)..$^{30}$

Quem é então o senhor do 'barato', da 'viagem', da 'onda'? O indivíduo, a sociedade, o organismo, a coisa? Nenhum deles, parece-me, pois a 'onda' não tem senhor nem servo, controlador ou controlado: ela ocorre ou não ocorre, 'rola' ou não 'rola'. Ela é da ordem do evento. Não se 
trata, portanto, de saber quem é o senhor da 'onda', mas se ela passa ou não, acontece ou não. Problematizando ao modo de Tarde (1895a, p. 113), a questão decisiva não é ser ou não ser drogado, mas saber se há ou não há 'onda', 31 e o que ela carreia ou faz passar.

Colocar o problema segundo o modo do haver implica reconhecer "a transitividade intrínseca, a abertura originária a uma exterioridade" (Viveiros de Castro, 2003, p. 17) que, como evento, a 'onda' exige desde o início. Afinal, a 'onda' não é - tal como o expressa a gíria nativa - o outro nome da ação de mudança, de transformação, de diferenciação intensiva, em suma, da ação de outrem, da alter-ação? Não é essa a fórmula do êxtase? Em suma, se a 'onda' é evento, e se tal evento é da ordem da alter-ação, é porque é sempre outrem que a põe em movimento.

E se é difícil colocar a questão nesses termos é porque nos habituamos a pensar como se houvesse um repertório limitado, pronto e acabado, de "entidades primeiras", ao qual acrescentamos, como que a secundá-las, um repertório não menos limitado, pronto e acabado, de relações "segundas", ao mesmo tempo em que retiramos desse duplo movimento o corolário/ladainha de senhores e servos, autônomos e autômatos, sujeitos plenos e zumbis amaldiçoados. É também porque, nesse mesmo duplo movimento, nos habituamos a tratar separadamente, e a opor sistematicamente, fatos e fetiches, evidências e crenças, e a dele retirar esse outro corolário: de um lado especialistas e outros "homens de bem", de outro lado usuários e seus "maus hábitos" (ou tudo às avessas, como quando os usuários se arvoram sábios ou 'cabeças feitas' para denunciarem o 'mundo dos caretas').

As drogas são feitas, e nem por isso elas são menos reais; elas são fatos, e nem por isso elas são menos construídas. Propriamente falando, elas constituem isso que Latour ${ }^{32}$ apropriadamente chamou de "fatiche" (faitiche), palavra-valise que combina fato e fetiche. ${ }^{33} \mathrm{E}$, se as drogas são fatiches, é porque nem elas nem os usuários são meros intermediários, 
Revista de Antropologia, São Paulo, USP, 2006, v. 49 no 2.

mas compõem (uns e outros, como os outros aliud sem os quais não há, no presente caso, agenciamento-droga ou evento 'onda') "uma cadeia de mediadores na qual nenhum causa exatamente o seguinte, mas na qual cada um permite ao seguinte tornar-se por sua vez origem da ação de, literalmente, 'fazer causar' seu sucessor" (Latour, 1998, p. 197).

Em outras palavras, se é difícil colocar o problema nos termos dessa questão é porque é difícil, como notara Latour (id., p. 192), "se desintoxicar desta droga: o controle". Para renovar o próprio modo de problematização do "problema das drogas", é preciso, portanto e desde o início, "se emancipar da pesada droga da emancipação" (ibid.) e, em vez de, mais uma vez, repetir a ladainha de que o que conta são as drogas e suas propriedades intrínsecas, ou os organismos e suas predisposições biopsíquicas, ou a sociedade e suas capacidades adscritícias, ou os indivíduos e suas açôes calculadas, se bem que mal informadas, considerar o que "faz-fazer" (faire-faire) drogas e usuários, ou seja, a 'onda' e suas alter-açôes.

Mas, se é preciso levar em conta a 'onda' e suas alter-açôes, é preciso também não perder de vista que, como ações de outrem, aquelas produzidas sob o modo de auto-abandono são, por definição, surpreendentes ou imprevisíveis. Levando isso em conta, o problema das drogas fica assim reconfigurado: a questão decisiva não é mais a do controle, ou a da emancipação, mas a da qualidade das misturas ou das composições. Em outros termos, não se trata de nos livrarmos das drogas, tampouco de nos livrarmos a elas, mas de saber qualificar os modos de vida (e de morte) que com elas se agencia. Para isso, no entanto, é preciso ainda realizar outro movimento e reconhecer que não há apenas um modo de viver a vida (ou de experimentar a morte) e que, entre outros modos possíveis de atualizá-la (modos esses que não envolvem os mesmos riscos, nem realizam os mesmos eventos), uns preferem fazer da vida uma experiência que deve durar em extensão (mesmo que para isso seja preciso 
mobilizar uma série de drogas), enquanto outros consideram que vale mais a pena viver a vida intensamente (mesmo que para isso seja necessário mobilizar outra série de drogas, ou então as mesmas drogas, mas de outras maneiras).

\section{Fim da controvérsia, ou controvérsia, enfim?}

Finalizo retornando ao ponto de partida e indagando aonde todo esse percurso nos leva: a uma inversão pura e simples do paradigma repressivo ou do consenso moral? Absolutamente, não me parece o caso, embora não possa evitar que leitores apressados, sejam eles "homens de bem" ou "de maus hábitos", 'caretas' ou 'cabeças feitas', tentem nele encontrar, para contornar as questôes espinhosas aqui levantadas, nada além que uma espécie de mal disfarçada apologia às drogas. Contra esse tipo de recurso que esteriliza o debate de antemão, só tenho a argumentar que sua força aparente provém do gênero de operações bélicas que ele põe em jogo e que, no mais das vezes, se valem da política de terra (ou argumentos) arrasada(os). Como notaram Stengers e Ralet (1991, p. 54), um dos problemas com o consenso moral ao qual as políticas nacionais antidrogas emprestam a força da lei e que contamina boa parte do debate analítico-político sobre o assunto é que ele "se exprime sempre em termos de frases-slogans gerais que designam aquele que não estaria de acordo enquanto inimigo público, ou, e isso particularmente se ele é um especialista dissidente, enquanto irresponsável" e, conseqüentemente, estabelece uma evidência que deve ser partilhada por todos, e não uma escolha susceptível de controvérsia. Assim, notam os autores, nas condiçôes atuais de "guerra às drogas", em que, muito além das metáforas, prevalecem as práticas bélicas, qualquer recalcitrância é percebida como perfídia, o que esteriliza o debate e compromete a busca de alter- 
nativas conseqüentes. É para alimentar o debate, para manter a controvérsia em aberto e, assim, contribuir para a busca conseqüente de alternativas que este texto foi escrito. E o que ele propõe, mais uma vez, não é a inversão do consenso moral, mas a afirmação eticamente sustentada, ao modo de Spinoza, da pluralidade imanente dos modos de existência. Se fui bem-sucedido nessa tarefa que me impus, cabe a outrem decidir...

\section{Notas}

1 Este texto capitaliza diferentes projetos de pesquisa apoiados pela PRPq da UFMG (modalidade Recém-doutor), pela CAPES (modalidade Pós-doutorado no exterior) e pelo $\mathrm{CNPq}$ (modalidade PIBIC). Sou especialmente grato aos usuários que se dispuseram a colaborar com a pesquisa, bem como a José Ronaldo Fassheber, Pedro Rocha e Cecília Chaves, que atuaram como meus assistentes de pesquisa, o primeiro em Juiz de Fora e os outros dois em Belo Horizonte. Sou grato ainda a Antoine Hennion e a Dominique Linhardt, bem como aos que participaram do seminário doutoral do CSI da ENSMP em 2005, por terem permitido testar algumas das idéias aqui expostas quando por lá estive; aos estudantes que discutiram este texto comigo no ateliê do LACS, particularmente a Brisa Catão, Camila de Caux, Isabel Luscher, Fernando Lima, Francilins Castilho, Letícia Cesarino, Patrick Arley, Pedro Pires, Rogério Brittes e Ruth Beirigo; aos(às) pareceristas anônimos(as) que avaliaram o texto; e a Lêda Brant, que sugeriu os acertos finais. Como de praxe, nenhum deles é responsável pelos erros remanescentes. Neste texto, todos os nomes seguidos de asteriscos são nomes fictícios de usuários de drogas entrevistados em Juiz de Fora (1998-1999) e em Belo Horizonte (2003-2004). Os próprios usuários foram solicitados a escolher seus respectivos nomes fictícios, daí a bizarria de alguns deles. As palavras ou frases entre aspas simples são termos ou expressōes nativas, a maioria de uso corrente entre usuários. As traduçôes de citações de edições estrangeiras de obras utilizadas neste texto são de minha autoria.

2 Coordenador do LACS, organizador da coletânea Monadologia e sociologia e outros ensaios (2007) e autor de Antes Tarde do que nunca: Gabriel Tarde e a emergência das ciências sociais (2000). 
3 O consenso moral não é auto-evidente, decerto, mas nem por isso me parece menos efetivo. São vários os dissensos, no entanto. No âmbito das políticas oficiais, a experiência holandesa persiste como a exceção paradigmática, seguida de perto pela dinamarquesa, mas há também experiências recentes - se bem que de caráter mais localizado - em curso em países como Inglaterra, Suíça e Portugal. Sobre a experiência holandesa e o consenso moral em torno das drogas, ver Isabelle Stengers e Olivier Ralet (1991).

4 A introdução de novas drogas no Velho Mundo após a conquista da América suscitou, aqui e ali, expedientes repressivos mais ou menos contundentes, sendo a pena capital imposta aos usuários de tabaco na Rússia do século XVII o caso mais notável (Braudel, 1979, p. 232). De todo modo, esses expedientes repressivos não se propagaram, sendo, na maioria dos casos, preteridos em favor de políticas de taxação pura e simples, de modo que até o fim do século XIX praticamente todas as substâncias hoje consideradas drogas e que eram então conhecidas estavam relativamente disponíveis para consumo sem maiores interdiçōes legais. Ver David Musto (1973), Howard Morgan (1981), Antonio Escohotado (1994) e David Courtwright (2001).

5 Tratei desses dois pontos em outro lugar (Vargas, 2001, pp. 196-215), por isso não os retomo aqui. Quanto ao segundo ponto, ver adiante nota 15. Quanto ao primeiro ponto, lembro apenas que essa uniformidade está historicamente relacionada com a paulatina imposição do que Sebastian Scheerer (1991, p. 170) chamou de um "controle internacional compulsório cooperativo" em torno das drogas. Sinteticamente, essa imposição resulta de um processo desencadeado a partir do fim do século XIX em torno do "problema do ópio", consolidado com a conversão do problema do ópio em "problema das drogas" no encerramento da Convenção de Haia em 1912, e exacerbado na década de 80 do século passado com a declaração de "guerra às drogas". Sobre a Convenção de Haia e a transformação do problema do ópio em problema de drogas, ver Scheerer (id.). Sobre o consumo de ópio na China nos séculos XVIII e XIX e o problema do ópio, ver Wolfgang Schivelbusch (1980, pp. 215-23), Marshall Sahlins (1988), Edson Passetti (1991, pp. 25-35) e Escohotado (1994, pp. 68-74). Sobre a situação das drogas nos Estados Unidos na virada do século XIX para o XX, o movimento da Temperança e as legislaçôes norte-americanas a respeito das drogas, que impactaram a conversão do problema de ópio em problema de drogas, ver Musto (1973) e Morgan (1981). Para uma interpretação alternativa, ver Courtwright (2001). 
6 Ver ainda Elliott Ross e Alfred Gilman (1987, p. 23), François Chast (1995, pp. 166-70) e Jandira Masur e Elisaldo Carlini (1989, p. 35).

7 "Esta teoria sugere que, do mesmo modo que o diabético é deficiente em insulina, pode existir [entre usuários de drogas] uma fraqueza biológica ou genética que pode ser compensada pela administração de drogas psicoativas específicas" (UNODC, 1997, p. 46).

8 Ver ainda Sigmund Freud (1920 e 1930).

9 O capítulo de World Drug Report que sintetizo aqui não faz referência a abordagens como as de David Le Breton, embora distinga usos "tradicionais" (ou culturalmente estabelecidos) e usos "modernos" de drogas. Se a incluo aqui é porque, diferentemente das outras, ela é de cunho "culturalista", mas também e sobretudo porque, apesar disso, ela, como as outras, recorre à noção de erro ou a algum dos seus vizinhos semânticos para dar conta das experiências contemporâneas de consumo de drogas. Ver Le Breton (1991) para as práticas de risco, uso de drogas inclusive, e Le Breton (1990) para a "crise de sentido" do mundo moderno.

10 Ver especialmente Outsiders, de Howard Becker (1963). Nesse clássico, Becker considera que o hábito de uso de drogas é constituído por meio de processos interativos de aprendizado e de inserção em grupos sociais, e que desviantes são as condutas publicamente rotuladas como ofensivas ou transgressoras, vale dizer, aquelas que são acusadas de fracassarem na obediência às regras socialmente estabelecidas.

11 O World Drug Report não apresenta referências para estas três últimas abordagens; não obstante, elas fornecem alguns dos argumentos e muitas das palavras de ordem mais acionados nos debates públicos sobre o assunto.

12 Ver Olievenstein (1970) e Masur e Carlini (1989, p. 10), que utilizam os termos aqui aspeados.

13 Félix Guattari (1977, p. 47) também já alertara para os perigos decorrentes de definições epistemologicamente negativas, como essas que consideram "tais fenômenos como respostas coletivas improvisadas a uma carência”. Em vez disso, ele sugere que "dever-se-ia estudá-los como uma experimentação social na marra, em grande escala”. A sugestão parece-me pertinente, desde que não seja entendida enquanto uma atitude voluntarista, mas como um agenciamento coletivo que se situa aquém, ou se desenvolve além, do plano das ações voluntárias; e desde que não percamos de vista que, como em toda experimentação, seus resultados são incertos. 
14 Esquematicamente, enquanto certos usos de drogas são condenados porque fazem "mal" (causam dependência ou abreviam a vida), outros são incentivados porque fazem "bem" (combatem a dor e as doenças e, assim, adiam a morte), sendo essas diferenças entre o "bem" e o "mal" sustentadas pelo sucesso ou fracasso das drogas nos testes laboratoriais, que, não obstante, não colocam em questão o princípio de que a vida deve ser vivida em extensão.

15 Como observei anteriormente, o consenso moral não é auto-evidente, tampouco onipresente. De fato, as relaçôes que a maioria das sociedades contemporâneas mantém com as drogas jamais são unívocas, mas ambivalentemente marcadas pela repressão e pela incitação ao uso (logo, também à produção, à distribuição e à circulação, como o sabemos ao menos desde a famosa Introdução de Marx). Cabe notar que o processo de criminalização das drogas é contemporâneo, e o outro braço da pinça, do inédito e impressionante desenvolvimento da indústria farmacêutica, responsável pela introdução, sem precedentes em termos históricos, de uma pletora de novas drogas. Por conta disso, e seguindo uma sugestão de Néstor Perlongher (1987, p. 3), considero que tais relaçōes configuram um dispositivo das drogas num sentido próximo ao que Michel Foucault (1976) estabeleceu para o dispositivo da sexualidade. Como este, aquele envolve, simultaneamente, repressão $e$ incitação; como este, aquele também se define tanto ou mais por suas capacidades produtivas (ou seja, por aquilo que permitem, viabilizam, multiplicam, fomentam, liberam) do que por suas habilidades repressivas (ou seja, por aquilo que constrangem, interditam, bloqueiam ou excluem); mas, diferentemente deste, aquele se especifica ao se constituir em torno ou a partir das próprias coisas ou, mais precisamente, de uma variedade de substâncias mobilizadas como mediadores incontornáveis em muitas das práticas contemporâneas. A mobilização contemporânea de uma gama impressionante de substâncias tornadas necessárias para garantir nossas condições atuais de existência evidencia este último ponto. Portanto, o dispositivo das drogas não se resume a mecanismos de coação (por menos trivial que isso seja e por mais que uma leitura rasa de Foucault o possa sugerir), mas diz respeito diretamente a agenciamentos específicos de potencialização (ou de empowering, como se diz na América) de nossas capacidades de ação e de resistência: é em boa parte por conta da criação de inúmeras drogas que, por exemplo, somos hoje capazes de fazer coisas antes inimagináveis, como prolongar os limiares da vida, mas é também justamente pela potência (ou eficácia) das drogas que 
corremos certos riscos antes praticamente inconcebíveis. A questão é que tal potencialização não aponta sempre para as mesmas direções: do ponto de vista das relaçôes bioquímicas consideradas em sentido estrito, não existem alguns efeitos que seriam "desejáveis" e outros que seriam "colaterais", "secundários", "adversos" etc., mas apenas e tão-somente efeitos. Daí que a distinção entre "efeitos desejados", "colaterais", "secundários" e "adversos", que, de modo amplo e mediante o acionamento de critérios clínicos, serve de base para a prescrição (medicamentosa) de drogas e para a restrição (de usos não medicamentosos) de drogas, apresenta variaçôes consideráveis conforme os agenciamentos específicos em que as drogas são mobilizadas. Cabe notar ainda que os processos de crimininalização das drogas e daquilo que autores como Jean-Pierre Dupuy e Serge Karsenty (1974), além de Ivan Illich (1975), chamaram de "invasão farmacêutica" também são contemporâneos à brutal restrição semântica do vocábulo. Cunhado no século XIV para designar uma ampla gama de substâncias, particularmente as especiarias provenientes do Oriente, o vocábulo droga veio a ter seu sentido restrito a substâncias psicotrópicas ou estupefacientes, bem como ao que faz mal ou é ruim, apenas no início do século XX, num processo que reservou os vocábulos fármacos ou medicamentos para as drogas reconhecidas como de uso terapêutico. Entretanto, apesar das tentativas de restrição dos sentidos do vocábulo, a ambigüidade do termo permanece e evidencia seu pertencimento a um mesmo dispositivo, já que, por exemplo, ainda continuamos, em muitos países, a adquirir nossos medicamentos em drogarias. Sobre esses pontos, ver Vargas (2001, pp. 65-94 e 204-14) e Vargas (2005).

16 Como um absurdo aparente, diga-se logo, já que as respostas então fornecidas o são exatamente para mostrar que por trás do absurdo escondem-se operaçōes lógicas que apenas um experto esperto (isto é, um analista atento) é capaz de revelar, num movimento cuja expressão "redução de absurdo" parece caracterizar adequadamente.

17 Esse reconhecimento se expressa, por exemplo, na seleção das 'quebradas' (ver nota 19), bem como das drogas e doses usadas. Isso não quer dizer que riscos não sejam corridos, por vezes de forma mais ou menos inconseqüente, não sendo raros os casos em que experiências de consumo acabem desandando em muito sofrimento, ou morte. 
18 Como Foucault (1967) já havia observado, "a intensidade, muito antes de ser graduada pela representação, é em si mesma uma pura diferença: diferença que se desdobra e repete, diferença que se contrai ou dilata, ponto singular que encerra ou solta, no seu agudo acontecimento, indefinidas repetiçôes. [...] Dissolução do eu”.

19 Na prática, uma 'quebrada' não é necessariamente um lugar em particular, mas qualquer lugar que possa se mostrar propício ao consumo de certas drogas. Geralmente, mais do que um lugar específico, trata-se de uma situação, um 'tipo de ambiente', onde certos lugares, sob certas condições, podem funcionar como uma 'quebrada'. Entre essas condiçôes, a mais óbvia é evitar, durante ou logo após o uso da droga, a aparição repentina de presenças 'inoportunas': polícia, família ou outros 'caretas' que reprimem o uso, mas também usuários 'abusados' - 'chatos', 'pidōes' ou 'fominhas' - que rompem os códigos do circuito por solicitarem demais sem fazerem as devidas prestações.

20 Especialistas no assunto sabem há muito tempo que isso que costumam chamar de o "meio social" impacta diretamente as condiçôes de uso de drogas. Uma tese corrente entre eles é a de que os usuários se tornam usuários porque o meio social impõe, ou seja, porque as drogas são um modo privilegiado - ao menos em certos casos - para viabilizar o ingresso ou marcar o pertencimento de alguém a determinado grupo social (Becker, 1963 e 1974; Olievenstein, 1970; Velho, 1998). Desse ponto de vista, a prática em questão - o uso de drogas - seria de algum modo a resultante de relações sociais preestabelecidas - o grupo social. Se bem que perspicaz, essa perspectiva considera apenas parte do problema, e deixa de lado um ponto fundamental: precisamente a prática em questão. Considerando que o que está em jogo são práticas que envolvem riscos inequívocos, o problema do recurso às drogas, e não a qualquer outra coisa, parece-me decisivo, embora tenha sido subexplorado até o momento. A distinção proposta por Sahlins (1985, p. 47) entre estruturas prescritivas e estruturas performativas pode ser útil aqui, pois ela permite tratar mais seriamente a hipótese segundo a qual usar drogas com alguém é um modo privilegiado - em certos casos e sob certas circunstâncias, nunca é demasiado repetir - para fazer desse alguém um 'amigo'. Enfim, se relações criam práticas, práticas também criam relaçôes: muitos vínculos de amizade surgem e permanecem porque articulam usuários de drogas. Experiências compartilhadas de usos de drogas podem causar morte, hábito, vício ou desvio; mas também po- 
dem fazer 'amigos'; o predomínio dos vínculos de afinidade sobre os de consangüinidade entre os usuários de drogas ilícitas aponta nessa direção. Como usuários costumam dizer, usar drogas é uma 'coisa bastante social', algo capaz de promover uma "aproximação das pessoas", de criar vínculos.

Essa preferência pelos 'amigos' como companhias no uso de drogas de uso ilícito não é prerrogativa exclusiva dos usuários contatados. No survey que realizamos com estudantes da UFJF (Vargas, 2001, pp. 362-4), observamos que os primeiros usos e os usos habituais dessas drogas costumam ocorrer entre pessoas que mantêm, entre si, preferencialmente relaçôes da ordem da afinidade (cerca de $9 \mathrm{em}$ cada 10 usaram, pela primeira vez, com amigos, colegas ou vizinhos); já o uso de álcool etílico, se bem que envolva majoritariamente pessoas cujos vínculos com o usuário são da ordem da afinidade, envolve a companhia de familiares proporcionalmente bem mais do que as drogas de uso ilícito o fazem. Quanto ao uso de psicotrópicos de uso controlado, o survey apontou que a indicação médica prevalece em mais de $50 \%$ dos casos - sendo notável, diga-se de passagem, a elevada porcentagem em que essa não é a regra, já que se trata de psicotrópicos de uso controlado.

21 Retomo aqui a diferença entre intermediários e mediadores tal como formulada por Latour (2005, pp. 37-42 e 232-41). Segundo ele, um intermediário acrescenta "predicabilidade ao estabelecido", pois "transporta significado ou força sem transformação"; sendo assim, os intermediários freqüentemente são ignorados, pois o que conta são as causas que eles transportam sem que façam intervir nenhuma diferença, nenhuma bifurcação nos efeitos que elas ocasionam; quanto aos mediadores, é necessário sempre levá-los em conta, pois eles "transformam, transladam, distorcem, modificam os significados ou os elementos que eles supostamente carregam", de tal forma que fazem o estabelecido "bifurcar em vários caminhos inesperados" (id., pp. 39 e 202). Os mediadores, portanto, não são causas, mas o que "faz-fazer" (faire-faire), o que atualiza diferenças.

22 Decerto, as bruxas não voavam para o Sabá montadas sobre suas vassouras, mesmo sob o efeito da beladona; não obstante, nem por isso elas viajavam menos, embora se tratasse, no caso, de "viagens imóveis". Sobre as viagens das bruxas na Europa medieval, ver Michael Harner (1972). Sobre as viagens imóveis, ver Deleuze e Guattari (1980a). 
23 São recorrentes os relatos em que usuários deploram a ocorrência de 'ondas ruins', freqüentemente relacionadas à presença de pessoas 'inconvenientes' (flagrantes parentais ou policiais) e a mal-estares físicos, mas também a situaçôes em que o auto-abandono torna-se demasiado intenso, quando se teme que a 'viagem' seja sem volta ou não tenha fim.

24 Para Geertz, as brigas de galos não constituem atividades irracionais porque "o acesso ao significado mais do que compensa o custo econômico envolvido", tudo isso, insiste, se levarmos em conta que "a imposição do significado na vida é o fim supremo e a condição primária da existência humana" (Geertz, 1973b, p. 434). Assim, se "o homem é um animal suspenso em teias de significados que ele mesmo teceu” (id., 1973a, p. 5), então esse animal é capaz de colocar outros para brigar de modo a encenar por meio destes uma espécie de fábula esopiana (id., 1973b, p. 436), um texto cultural no qual cada um "forma e descobre seu temperamento e a têmpera de sua sociedade ao mesmo tempo" (id., p. 451). Nesse esquema, os galos são acionados por serem capazes de "dizer algo sobre algo" (id., p. 448) e por comporem, assim, uma alegoria moral do modo de vida balinês, o que equivale a dizer que na briga de galos quem briga são os homens, já que nesse esquema os galos não passam de intermediários.

25 Quero com isso dizer que, se aplicássemos a solução de Geertz ao uso de drogas, o recurso às drogas propriamente ditas permaneceria inexplicável, pois ele não faria a menor diferença. Nesse esquema as drogas não passariam de meros intermediários, pois não seriam capazes de alterar a cadeia de transmissão do que, na ótica de Geertz, realmente interessa: os códigos sociais. Esse esquema interpretativo corre em paralelo com aquele proposto pela teoria do desvio, com o qual compartilha ao menos esse equívoco: não levar em conta, ou a sério, o próprio veículo por meio do qual os códigos sociais são agenciados (ver nota 20). Sustento, no entanto, que o "problema" das drogas, nos vários sentidos do termo, é que elas operam como mediadores e, enquanto tais, são agentes de alter-açôes. Retomo aqui a diferença entre intermediários e mediadores (ver nota 21).

26 Resumo aqui, certamente de modo apressado, um argumento adaptado com base nas noções de "produção consumptiva", de "despesa improdutiva" e de "modos de produção de pessoas", tal como essas noções foram desenvolvidas, respectivamente, por Karl Marx, Georges Bataille e Chris Gregory. Esse argumento sugere que 
as modalidades de uso não medicamentoso de drogas colocariam em jogo uma ética da intensidade, que contrasta com a ética da extensão que prevaleceria nos usos médicos de drogas. Embora contrastantes, essas éticas mantêm relações ambivalentes entre si. Para que isso se evidencie, é necessário evitar reduzir a problemática ética aos preceitos morais, bem como uma leitura racionalista da extensão (que a confundiria com quantidade) e uma leitura romântica da intensidade (que a confundiria com qualidade); e considerar a extensão e a intensidade como distribuídas numa polaridade que, sendo tão tensa quanto tênue, é vazada por inúmeras situações intermediárias. Sobre esses pontos, ver Vargas (2001, pp. 551-61).

27 Sobre o conceito de alteração como ação de outrem e como diferenciação intensiva, ver Viveiros de Castro (2001, p. 16), de quem tomo emprestada a idéia de alteração. Ainda sobre esse ponto, a leitura de Latour (2005, pp. 43ss) foi fundamental.

28 Tarde colocara essa questão há um século $(1897$, p. 312), algum tempo depois de ter afirmado que "todo fenômeno não é senão uma nebulosa decomponível em açôes emanadas de uma infinidade de agentes que são outros tantos pequenos deuses invisíveis e inumeráveis" (1895a, p. 78).

29 Além disso, e em outro registro, cabe indagar: se os usuários de drogas de uso ilícito são, como se diz, "desajustados sociais", pertencentes a grupos sociais mais ou menos marginais ou liminares, por que nem todo desajustado social é usuário de drogas? Tomo aqui emprestado de Marcio Goldman (1998, p. 11) a fórmula de Jean Paul Sartre, segundo a qual "é bem fácil revelar as origens burguesas de um grande escritor; mais difícil, nessa chave, é dar conta do fato de que nem todo burguês é um grande escritor".

30 Ver Vargas (2007, pp. 41-2) para a opção de tradução do francês possession por possessão (termo que designa ações reversas, ou ao menos reversíveis), e não por posse (termo que remete a ações de mão única, ações nas quais a assimetria da relação já vem definida de antemão).

31 Como provocativamente observou Tarde (1895a, p. 113), toda a filosofia fundou-se até agora no verbo $\operatorname{Ser}$ [Etre], cuja definição parecia a pedra filosofal a descobrir. Pode-se afirmar que, se tivesse sido fundada no verbo Haver [Avoir], muitos debates estéreis, muitos passos do espírito no mesmo lugar teriam sido evitados. Deste princípio, eu sou [je suis], é impossível deduzir, mesmo com toda a sutileza 
do mundo, qualquer outra existência além da minha; daí a negação da realidade exterior. Mas se coloque em primeiro lugar este postulado ' $E u$ hei [J'ai] como fato fundamental, o havido [eu] e o havendo [ayant] são dados ao mesmo tempo como inseparáveis.

$\mathrm{O}$ avoir francês pode ser vertido para o português quer como Ter, quer como $\mathrm{Ha}$ ver. Se acompanho Viveiros de Castro e opto por Haver, em vez de Ter, é porque em português o verbo Ter absorveu todo o sentido possessivo do Avoir francês, enquanto a designação do sentido de existência impessoal ficou a cargo do Haver (Vargas, 2007, pp. 42-4). Como notou Santoro (2004, p. 543), o há português "porta uma idéia de presença instantânea no mundo, sem outro suporte além do próprio advento" (id., p. 544), como na notável expressão: há o que existe. No presente caso, essa expressão torna-se ainda mais notável se nos lembrarmos daquela outra magistral expressão de Tarde: "existir é diferir" (1895a, p. 98). Perguntar, então, se há ou não há 'onda' é indagar, no sentido propriamente tardeano da expressão, se existe ou não diferença no curso da ação, ou, simplesmente, como veremos a seguir, se há alter-ação.

32 Aliás, arguto leitor atual de Tarde (Latour, 2001 e 2005).

33 Sobre a noção de fatiche, ver Latour (1996); sobre as drogas como fatiches, ver Latour (1996, 97n; 1998).

\section{Bibliografia}

AKRICH, Madeleine

1995 "Petite anthropologie du médicament", Techniques \& Culture, Paris, vol. 25-6: $129-57$.

BATAILLE, Georges

1933[1967] “La Notion de Dépense", in La Part Maudite - précédé de La Notion de Dépense, Paris, Minuit, pp. 23-45. 
Revista de Antropologia, São Paulo, USP, 2006, v. 49 no 2.

BECKER, Howard

1963[1997] Outsiders: Studies in the Sociology of Deviance, New York, The Free Press, $215 \mathrm{pp}$.

1974[1977] "Consciência, poder e efeito da droga", in Uma teoria da ação coletiva, Rio de Janeiro, Zahar, pp. 181-204.

BRAUDEL, Fernand

1979[1997] Civilização material, economia e capitalismo, séculos XV-XVIII - as estruturas do cotidiano, São Paulo, Martins Fontes, 541 pp.

CABALLERO, Francis

1992

"Drogues et droits de l'homme en France", in CABALLERO, Francis (org.), Drogue et droits de l'homme, Paris, Les Empêcheurs de Penser en Rond, pp. 13-30.

CAIAFA, Janice

Movimento punk na cidade - a invasão dos bandos sub, Rio de Janeiro, Jorge Zahar, 148 pp.

CASSIN, Barbara

1998 "Présentation - quand lire, c'est faire", in PARMÉNIDE, Sur la Nature ou sur l'Étant, Paris, Seuil, pp. 9-68.

CHAST, François

1995 Histoire contemporaine des médicaments, Paris, La Découverte, 390 pp.

COURTWRIGHT, David

2001 Forces of Habit - Drugs and the Making Of the Modern World, Cambridge, Massachusetts, Harvard University Press, 277 pp.

DAGOGNET, François \& PIGNARRE, Philippe

2005100 mots pour comprendre les médicaments - comment on vous soigne, Paris, Les Empêcheurs de Penser en Rond, 396 pp.

DELEUZE, Gilles \& GUATTARI, Félix

1980a[1996] "28 de Novembro de 1947 - Como criar para si um corpo sem órgãos", in Mil Platôs - capitalismo e esquizofrenia, vol. 3, Rio de Janeiro, Editora 34, pp. 9-29. 
1980b[1997] "1227 - Tratado de Nomadologia: a máquina de guerra”, in Mil Platôs - capitalismo e esquizofrenia, vol. 5, Rio de Janeiro, Editora 34, pp. 11-110.

DUPUY, Jean-Pierre \& KARSENTY, Serge

1974[1979] A invasão farmacêutica, Rio de Janeiro, Graal, 272 pp.

ESCOHOTADO, Antonio

1994 Las drogas - de los orígenes a la prohibición, Madrid, Alianza, 96 pp.

FOUCAULT, Michel

1967[1980] Nietzsche, Freud e Marx - Theatrum Philosophicum, Porto, Anagrama.

1976[1982] História da sexualidade I - a vontade de saber, Rio de Janeiro, Graal, 152 pp.

FREUD, Sigmund

1920[1981] "Mas allá del Principio del Placer", in Obras Completas - Tomo III, Madrid, Editorial Biblioteca Nueva, pp. 2.507-41.

1930[1981] "El malestar en la cultura", in Obras Completas - Tomo III, Madrid, Editorial Biblioteca Nueva, pp. 3.017-67.

GEERTZ, Clifford

1973a[2000] "Thick Description: Toward an Interpretative Theory of Culture", in The Interpretation of Cultures, New York, Basic Books, pp. 3-30.

1973b[2000] "Deep Play: Notes on the Balinese Cockfight", in The Interpretation of Cultures, New York, Basic Books, pp. 412-53.

GOLDMAN, Marcio

1998 "A experiência de Lienhardt: uma teoria etnográfica da religião", Religiāo e Sociedade, vol. 19(2): 9-30.

GOMART, Emilie \& HENNION, Antoine

1999

"A Sociology of Attachment: Music Amateurs, Drug Users", in LAW, John \& HASSARD, John (orgs.), Actor Network Theory and After, Oxford, Blackwell Publishers, pp. 220-47.

GREGORY, Chris

1982

Gifts and Commodities, London, Academic Press, 242 pp. 
GUATTARI, Félix

1977[1985] "Gangues em Nova Iorque", in Revolução Molecular-pulsaçōes políticas do desejo, São Paulo, Brasiliense, pp. 46-8.

HARNER, Michael

1972[1976] "El rol de las plantas alucinógenas en la brujería europea", in HARNER, Michael (org.), Alucinógenos y chamanismo, Madrid, Guadarrama, pp. 138-60.

ILLICH, Ivan

1975 A expropriação da saúde - nêmesis da medicina, 3.ed., Rio de Janeiro, Nova Fronteira, 196 pp.

LATOUR, Bruno

1996 Petite réflexion sur le culte moderne des dieux faitiches, Paris, Les Empêcheurs de Penser en Rond, 103 pp.

1998[2000] "Factures/fractures: de la notion de réseau à celle d'attachement", in MICOUD, André \& PERONI, Michel (orgs.), Ce qui nous relie, Paris, L'Aube Éditions, pp. 189-208.

1999[2001] A esperança de Pandora - ensaios sobre a realidade dos estudos cientificos, Bauru, Edusc, $371 \mathrm{pp}$.

2001 "Gabriel Tarde and the End of the Social", in JOYCE, Patrick (org.), The Social and Its Problems, Londres, Routledge, pp. 117-32.

2005 Reassembling the Social: an Introduction to Actor-Network-Theory, Oxford, Oxford University Press, 325 pp.

LE BRETON, David

1990[1995] Anthropologie du Corps et Modernité, Paris, PUF, 263 pp.

1991[1996] Passions du risque, Paris, Métailié, 190 pp.

MARX, Karl

1857[1978] "Introdução à crítica da economia política", in GIANNOTTI, José Arthur (org.), Marx, São Paulo, Abril, Coleção “Os Pensadores”, pp. 103-25.

MASUR, Jandira \& CARLINI, Elisaldo

1989[1993] Drogas - subsídios para uma discussão, São Paulo, Brasiliense, 114 pp. 
MINTZ, Sidney W.

1985[1986] Sweetness and Power: the Place of Sugar in Modern History, New York, Viking Penguin, $274 \mathrm{pp}$.

MORGAN, Howard Wayne

1981[1982] Drugs in America - a Social History 1800-1900, New York, Syracuse University Press, 233 pp.

MUSTO, David

1973[1987] The American Disease: Origins of Narcotic Control, Oxford, Oxford University Press, $400 \mathrm{pp}$.

OLIEVENSTEIN, Claude

1970[1984] A droga-drogas e toxicômanos, São Paulo, Brasiliense, 144 pp.

PASSETTI, Edson

1991 Das "fumeries" ao narcotráfico, São Paulo, Educ, 153 pp.

\section{PERLONGHER, Néstor}

1987 "A produção do êxtase no circuito da droga", II Congresso Internacional sobre Toxicomanias, I Congresso Brasileiro sobre consumo de drogas, São Paulo, mimeo, 16 pp.

1990[1994] "Droga e êxtase", Religião e Sociedade, vol. 16(3): 8-23.

PIGNARRE, Philippe

1997[1999] O que é o medicamento? Um objeto estranho entre ciência, mercado e sociedade, Rio de Janeiro, Editora 34, 150 pp.

ROSS, Elliott \& GILMAN, Alfred

1987 "Farmacodinâmica: mecanismos de ação das drogas e relação entre concentração da droga e seu efeito", in GOODMAN \& GILMAN (orgs.), As bases farmacológicas da terapêtutica, Rio de Janeiro, Guanabara, pp. 23-31.

SAHLINS, Marshal

1985 "Suplemento à viagem de Cook; ou 'le calcul sauvage", in Ilhas da História, Rio de Janeiro, Zahar, pp. 23-59. 
SANTORO, Fernando

"Há, haver", in CASSIN, Bárbara (org.), Vocabulaire européen des philosophies dictionnaire des intraduisibles, Paris, Éditions du Seuil/Dictionnaires Le Robert, pp. 543-5.

SCHEERER, Sebastian

1991[1993] "Estabelecendo o controle sobre a cocaína (1910-1920)", in BASTOS, F. I. \& GONÇALVES, O. D. (orgs.), Drogas: é legal? Um debate autorizado, Rio de Janeiro, Imago, pp. 169-92.

SCHIVELBUSCH, Wolfgang

1980[1993] Tastes of Paradises - a Social History of Spices, Stimulants, and Intoxicants, New York, Vintage Books, 237 pp.

STENGERS, Isabelle \& RALET, Olivier

1991 Drogues, le défi hollandais, Paris, Les Empêcheurs de Penser en Rond, 116 pp.

TARDE, Gabriel

1890[2001] Les lois de l'imitation, Paris, Les Empêcheurs de Penser en Rond, 448 pp.

1895a[2007] "Monadologia e sociologia", in Monadologia e sociologia e outros ensaios, São Paulo, Cosacnaify, pp. 51-131.

1895b[1999] La logique sociale, Paris, Les Empêcheurs de Penser en Rond, 603 pp.

1897[1999] L'opposition universelle - essai d'une théorie des contraires, Paris, Les Empêcheurs de Penser en Rond, 408 pp.

UNODC (United Nations Office on Drugs and Crime)

1997 Word Drug Report, New York, United Nations Publications, 201 pp.

VARGAS, Eduardo V.

2001 Entre a extensão e a intensidade: corporalidade, subjetivação e uso de "drogas", Belo Horizonte, 600 pp., tese, UFMG.

2005 "Drogas: armas ou ferramentas?", in MINAYO, Cecília \& COIMBRA, Carlos (orgs.), Criticas e atuantes: Ciências sociais e humanas em saúde na América Lati$n a$, Rio de Janeiro, Fiocruz, pp. 587-608. 

sociologia e outros ensaios, São Paulo, Cosacnaify, pp. 7-50.

VELHO, Gilberto

$1998 \quad$ Nobres e anjos - um estudo de tóxicos e hierarquia, Rio de Janeiro, Fundação Getúlio Vargas, 214 pp.

VIVEIROS DE CASTRO, Eduardo

2001 "A propriedade do conceito", texto apresentado no ST 23: Uma notável reviravolta: antropologia (brasileira) e filosofia (indígena), Reunião Anual da ANPOCS, Caxambu, 52 pp.

2003

"And - After-dinner speech given at Anthropology and Science, The 5th Decennial Conference of the Association of Social Anthropologists of the UK and Commonwealth", Manchester Papers in Social Anthropology, vol. 7, Manchester, University of Manchester, 20 pp.

WHITEHEAD, Alfred North

ZALUAR, Alba

1993[1994] "A criminalização das drogas e o reencantamento do mal", in Condomínio do Diabo, Rio de Janeiro, Revan/UFRJ, pp. 235-54. 


\begin{abstract}
This article reflects on the types of questions and answers that researchers usually formulate regarding the uses of drugs and take into account another way of thinking these practices. We suggest that it is not enough to inquire "why people use drugs" and "which is the meaning of drug's use"; neither to be contented with the answers... (...) Therefore, we also propose other answers. (...), but it asks for modalities of (in)action like those present on the paradox of passion or on deep play. We support that the event 'high' points for singular ways of engaging in the world, ways in which substances are indispensable mediators. Finally we suggest that instead of asking who controls the 'high', it is better to ask if the 'high' happens or not, or after Gabriel Tarde, if there is an alter-action or not.
\end{abstract}

KEY-WORDS: drugs, medicines, event, action, Gabriel Tarde.

Aceito em novembro de 2006. 